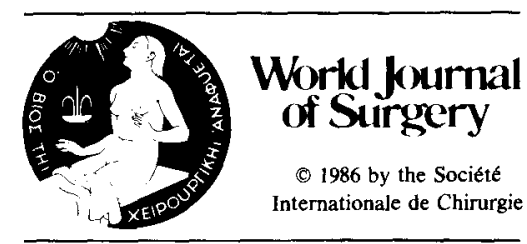

\title{
Plasma Gut Hormone Levels in 37 Patients with Pheochromocytomas
}

\author{
Aaron I. Vinik, M.D., Brahm Shapiro, MB.Ch.B., Ph.D., and Norman W. Thompson, M.D. \\ Department of Internal Medicine, Divisions of Endocrinology and Metabolism, and Nuclear Medicine \\ and the Department of Surgery, University of Michigan Medical Center, Ann Arbor, Michigan, U.S.A.
}

Pheochromocytomas are usually recognized by the effects of overproduction of catecholamines, but there are clinical features that cannot be ascribed to catecholamine excess that may be due to vasoactive peptides. We, therefore, measured blood levels of vasoactive intestinal peptides (VIP), substance P, somatostatin (SS), and motilin in 50 instances in 37 patients with pheochromocytomas-21 malignant, 10 benign intra-adrenal, and 6 ectopic (5 paracardial and 1 perirenal). Hormone levels were considered raised if the level was more than $3 \mathrm{~S}$.D. above the mean value found in 52 healthy subjects. Of the 37 patients, $20(54 \%)$ had an abnormality in 1 or more gut hormone levels. The most common abnormality was a raised SS in $9 / 37(24 \%)$. In addition to these, however, $3(8 \%)$ others had raised VIP, $5(13.5 \%)$ raised motilin, and $3(8 \%)$ raised substance $P$. Patients with benign adrenal adenomas had raised levels of $S S$ and substance $P$. Ectopic pheochromocytomas produced only SS in addition to catecholamines, but malignant pheochromocytomas could secrete all 4 peptides, and more than 1 in the same patient. We conclude that pheochromocytomas may secrete multiple vasoactive peptides, and they are more likely to do so if malignant. Somatostatin is the most commonly secreted peptide and is found with benign adrenal and ectopic (paracardiac) tumors. If the level of more than 1 peptide is elevated, the likelihood of malignancy is significantly increased.

Pheochromocytomas are unusual but by no means rare tumors with an incidence of $0.01 \%$ to $0.001 \%$

Presented at the International Association of Endocrine Surgeons in Paris, September 1985.

Reprint requests: Aaron I. Vinik, M.D., University of Michigan Medical Center, 1405 E. Ann Street, Room D2226 Medical Professional Building, Box 046, Ann Arbor, Michigan 48109, U.S.A.
[1-3]. The clinical manifestations of these tumors are protean and typically include hypertension (which may be severe, labile, paroxysmal, or may alternate with hypotension) and "spells" of episodic symptoms which tend to be stereotyped in each given patient and which may include various combinations of sweating, palpitations, pallor, anxiety, abdominal pain, chest pain, nausea, and tremor. These symptoms and signs may be ascribed to the increased levels of the catecholamines. The biochemical confirmation of the diagnosis lies in documenting this by assay of plasma catecholamine concentrations and/or urinary catecholamine excretion rates [4-6].

Pheochromocytomas are tumors derived from the chromaffin neuroendocrine cells of the sympathoadrenal medullary system and can occur at any site from the base of the skull to the pelvic floor. The most common site ( $90 \%$ ) is the adrenal medulla, the site of the majority of chromaffin tissues in the adult. Ten percent of lesions are extra-adrenal and most commonly occur in the para-aortic ganglia (including the organ of Zuckerkandl); other extraadrenal sites include the renal hilum; paravertebral autonomic, paracardiac, and cervical paraganglia, and the urinary bladder. Approximately $10 \%$ of pheochromocytomas are malignant and show either marked local invasive properties and/or metastasize, most commonly to the axial skeleton and less often to lymph nodes, liver, and lung.

The chromaffin cells form part of the APUD (amine precursor uptake and decarboxylation) system [7-10]. This system is believed to be embryologically derived from primitive neuroectoderm and includes the central nervous system as well as many components of the endocrine system, including the sympathoadrenal medullary system, parathyroid glands, $C$ cells of the thyroid gland, and possibly the 
endocrine pancreas and the enteric hormonal cell system.

The principal humoral factors secreted by the adrenomedullary sympathetic chromaffin system are the catecholamines including dopamine and norepinephrine. In the case of the adrenal medulla, an additional methyltransferase is present, which (in the presence of glucocorticoids from the adrenal cortex) converts norepinephrine to epinephrine. Although the biogenic amines are prominent in the secretory products of the chromaffin system, other factors are present. These include numerous peptides belonging to the group of so-called brain-gut peptides or neurohumoral factors [11-13]. Under this heading are included vasoactive intestinal peptides (VIP), substance $P$, somatostatin (SS), various opiate peptides, and motilin, which have been shown to occur in normal chromaffin tissues or tumors derived from such tissues [11]. The hypersecretion of these brain-gut neuropeptides may contribute to certain symptoms and signs that may occur with pheochromocytoma but in which hypercatecholaminemia cannot be clearly identified (e.g., flushing, bronchospasm, diarrhea, constipation) or may contribute in association with catecholamines to other symptoms (e.g., hyperglycemia, hypotension). This study undertook to measure a variety of brain-gut peptides in a group of patients with a variety of pheochromocytomas to determine the prevalence of hypersecretion.

\section{Materials and Methods}

\section{Patient Population}

A total of 37 patients with proven pheochromocytomas were studied. They were part of a large group referred for ${ }^{131}$ I meta-iodobenzylguanidine (MIBG) scintigraphy to locate suspected pheochromocytomas or to evaluate the extent of known disease. The nature of the lesions present was as follows: 21 malignant, 10 benign intra-adrenal, and 6 extraadrenal primary tumors ( 5 paracardiac and 1 perirenal). The clinical and hormonal details of individual patients are presented in Tables 1 and 2. Histologic confirmation of the tumor was obtained in every patient, either by examination of tissue excised following operation performed at this institution or by review of tissue blocks or sections obtained following operation elsewhere. The light microscopic features of pheochromocytomas were present in all patients and immunohistochemistry was positive for chromogranin and neuron-specific enolase in all those patients in whom this was sought.

\section{Laboratory Methods}

${ }^{131}$ I-MIBG scintigraphy was performed as described previously [14]. The images were interpreted using previously described criteria [14-16]. The results of ${ }^{131} \mathrm{I}$-scintigraphy were correlated with those of computed tomography (CT) scan, ultrasound, angiography, venous sampling, and surgical exploration (in various combinations).

Assays of catecholamines in plasma were carried out by the dual isotope radioenzymatic assay of Peuler and Johnson [17]. The least detection limit for epinephrine was 20 picograms $(\mathrm{pg}) / \mathrm{ml}$ and for norepinephrine it was $40 \mathrm{pg} / \mathrm{ml}$. The coefficient of interassay variability was $\pm 5 \%$. Blood samples were drawn in the fasted, resting, supine state through an indwelling needle left in situ for at least 30 minutes. Blood was placed in prechilled tubes on ice and the plasma was separated within 30 minutes and frozen at $-70^{\circ} \mathrm{C}$ until assay. The urinary excretion rates of catecholamines and catecholamine metabolites were measured on 12-hr overnight (7 P.M.-7 A.M.) urine collection. Excretion rates were expressed in $\mu \mathrm{g} / 24 \mathrm{hr}$ and are presented in Table 1 .

Blood samples for the measurement of peptide hormones were drawn in the fasted resting state into the following prechilled tubes, edetate (EDTA), EDTA with aprotinin (Trasylol FBA NJ $1,000 \mathrm{U} / \mathrm{ml}$ ), heparinized, and plain tubes for serum. Samples were placed on ice separated within 30 minutes and frozen at $-30^{\circ} \mathrm{C}$ until assay.

Plasma peptide hormone assays were carried out using previously described radioimmunoassays (somatostatin [18]; motilin [19]; VIP [20] and substance $P$ [21]). The intra-assay coefficient of variation of these assays was $<5 \%$ and all samples were run in the same assay for individual hormones. The crossreactions for SS28 in the SS14 assay was $66 \%$ and samples were not subjected to fractionation.

Statistical analysis of the significance of the relationship between hormone concentrations was carried out by the method of least means square regression and differences between groups by categorical analysis. Significance was accepted at the $5 \%$ level.

Immunohistochemistry was carried out by the method of Sternberger et al. [22] and tissue and blood levels of chromogranin and neuron-specific enolase as described previously [23, 24].

\section{Results}

The clinical features including the demographic, radiological, and scintigraphic data are presented in Table 1. The plasma and urinary catecholamines and hormone profiles are presented in Table 2.

Of the 37 patients, 21 were found to have malignant metastatic tumors, 10 had intra-adrenal tu- 
Table 1. Clinical features of excretion rates of catecholamines and catecholamine metabolites.

\begin{tabular}{|c|c|c|c|c|}
\hline Date & Patient & Nature of lesion & Radiographic data & MIBG scan \\
\hline $1 / 20 / 82$ & 1 & MEN IIa bilateral adr T & Unilateral adr $\mathrm{T}$ on $\mathrm{CT}$ scan & Abnormal $\mathrm{x} 1$ borderline $\mathrm{x} 1$ \\
\hline $7 / 8 / 82$ & 2 & Malig primary adr & Multiple mets bone scan & Multiple foci in skeleton \\
\hline $4 / 19 / 82$ & 3 & Malig primary extra-adr & Normal CT scan & Multiple foci in skeleton \\
\hline $1 / 13 / 83$ & 4 & Malig primary adr & $\begin{array}{l}\mathrm{CT} \text { abdominal mass and } \\
\text { lung mets }\end{array}$ & Uptake in both lung fields \\
\hline $4 / 7 / 82$ & 5 & Malig primary adr & Spinal mets on bone scan & $\begin{array}{l}\text { Uptake in spine and } \\
\text { abdomen }\end{array}$ \\
\hline $8 / 27 / 82$ & 6 & Malig primary adr & $\begin{array}{l}\text { MIBG-directed CT } \\
\text { intra-atrial } T\end{array}$ & Uptake in atria \\
\hline $2 / 12 / 82$ & 7 & Malig bilateral primary & Recurrent $\mathrm{L}$ adr $\mathrm{T}$ on CAT & $\begin{array}{l}\text { Uptake in adr, liver, } \\
\text { para-aortic }\end{array}$ \\
\hline $4 / 27 / 82$ & 8 & Bilateral adr & Bilat adr masses & Uptake in adr bilaterally \\
\hline $4 / 20 / 82$ & 9 & Malig adr + extra-adr & $\begin{array}{l}\text { CT abdominal mass mets in } \\
\text { skull }\end{array}$ & $\begin{array}{l}\text { Abnormal foci in skeleton } \\
\text { and abdomen }\end{array}$ \\
\hline $5 / 20 / 82$ & 10 & Malig primary adr & Bone scan multiple mets & Negative \\
\hline $2 / 26 / 82$ & 11 & Malig primary extra-adr & $\begin{array}{l}\text { CT para-aortic mass bone } \\
\text { mets }\end{array}$ & $\begin{array}{l}\text { Foci in skeleton and } \\
\text { para-aortic }\end{array}$ \\
\hline $7 / 19 / 82$ & 12 & Malig primary extra-adr & $\begin{array}{l}\text { Mets bone scan and x-ray } \\
\text { chest }\end{array}$ & $\begin{array}{l}\text { Foci in skeleton, lungs, } \\
\text { abdomen }\end{array}$ \\
\hline \multicolumn{5}{|l|}{$\begin{array}{l}11 / 15 / 82 \\
?\end{array}$} \\
\hline $9 / 28 / 81$ & 13 & Recurrent intra-adr & CT neg due to clips & Foci in adr bed \\
\hline $1 / 19 / 82$ & 14 & Malig primary bladder & $\begin{array}{l}\text { CT neg due to previous } \\
\text { surgery }\end{array}$ & Foci in liver \\
\hline $5 / 20 / 82$ & 15 & Malig primary adr & All studies neg & Foci in skeleton \\
\hline $\begin{array}{l}12 / 8 / 82 \\
\text { (preoperative) }\end{array}$ & 16 & Benign primary adr & CT unilateral adr T & Unilateral adr focus \\
\hline $\begin{array}{l}\text { 1/11/83 } \\
\text { (postoperative) }\end{array}$ & & & & Normal \\
\hline $\begin{array}{l}\text { Pre-op } \\
1 / 5 / 83\end{array}$ & 17 & Malig primary adr & MIBG-directed CT atrial T & $\begin{array}{l}\text { Focus in region of atria } \\
\text { Normal }\end{array}$ \\
\hline $7 / 8 / 82$ & 18 & Malig primary adr & CT mets to iliac crest & Focus in adr \\
\hline $3 / 11 / 82$ & 19 & Malig primary adr & $\begin{array}{l}\text { Multiple skeletal mets bone } \\
\text { scan }\end{array}$ & Multiple foci in skeleton \\
\hline \multicolumn{5}{|c|}{ 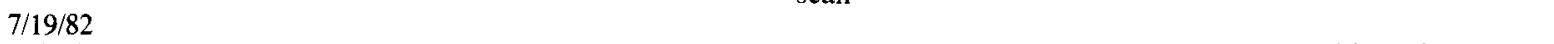 } \\
\hline $10 / 27 / 81$ & 20 & Benign primary paracardiac & $\begin{array}{l}\text { CT neg, MIBG-directed CT } \\
\text { atrial T }\end{array}$ & $\begin{array}{l}\text { Abnormal foci in atria } \\
\text { region }\end{array}$ \\
\hline \multicolumn{5}{|l|}{$\begin{array}{l}4 / 30 / 82 \\
\quad \text { (preoperative) }\end{array}$} \\
\hline $11 / 10 / 82$ & 21 & Benign intra-adr primary & $\mathrm{CT}$ unilateral adr $\mathrm{T}$ & Focus in adr \\
\hline $10 / 22 / 81$ & 22 & Malig extra-adr primary & CT pancreatic $\mathrm{T}$ & $\begin{array}{l}\text { Foci in liver and } \\
\text { para-aortic }\end{array}$ \\
\hline $5 / 20 / 82$ & 23 & Malig extra-adr primary & CT abdominal mass & $\begin{array}{l}\text { Foci in abdomen, chest, } \\
\text { occiput }\end{array}$ \\
\hline $\begin{array}{l}6 / 8 / 82 \\
2 / 4 / 82\end{array}$ & $\begin{array}{l}24 \\
25\end{array}$ & $\begin{array}{l}\text { Benign primary paracardiac } \\
\text { Not found }\end{array}$ & MIBG-directed CT atrial T & Focus in atria region \\
\hline $2 / 4 / 82$ & 26 & Malig right renal primary & $\mathrm{CT} R$ renal mass & $\mathrm{R}$ renal focus \\
\hline $1 / 13 / 83$ & 27 & Benign intra-adr primary & CT unilateral adr mass & Unilateral focus, in $\mathrm{R}$ adr \\
\hline $3 / 18 / 82$ & 28 & Malig extra-adr primary & CT neg & Multiple abdominal foci \\
\hline $8 / 26 / 82$ & 29 & Benign intra-adr primary & CT unilateral adr lesion & Single adr focus \\
\hline $12 / 1 / 81$ & 30 & Malig primary adr & CT multiple liver mets & Foci in liver and thoracic spine \\
\hline \multicolumn{5}{|l|}{$\begin{array}{l}4 / 7 / 82 \\
7 / 19 / 82\end{array}$} \\
\hline $10 / 22 / 81$ & 31 & Malig intra-abdominal & Para-aortic $\mathrm{T}$ masses & Foci in abdomen, neck, chest \\
\hline \multicolumn{5}{|l|}{$10 / 27 / 83$} \\
\hline \multicolumn{5}{|l|}{$1 / 10 / 83$} \\
\hline $1 / 18 / 83$ & & & & \\
\hline $9 / 4 / 82$ & 32 & Malig extra-adr primary & $\begin{array}{l}\text { ? abnormal para-aortic } \\
\text { region }\end{array}$ & Two foci in mid-abdomen \\
\hline $4 / 19 / 82$ & 33 & Malig extra-adr primary & Bone scan multiple mets & Multiple foci in skeleton \\
\hline $\begin{array}{l}\text { 8/20/82 } \\
\text { (preoperative) } \\
9 / 17 / 82 \\
\quad \text { (postoperative) }\end{array}$ & 34 & Benign paracardiac & Atrial $\mathrm{T}$ by dynamic CT & Focus in atria \\
\hline $2 / 4 / 82$ & 35 & Malig primary adr & $\begin{array}{l}\text { Multiple mets in lung and } \\
\text { bone }\end{array}$ & Uptake in adr, lung, bone \\
\hline $3 / 8 / 81$ & 36 & Malig intra-abdominal & CT neg due to surgery & Large para-aortic $T$ \\
\hline $10 / 12 / 82$ & 37 & Benign intra-adr primary & CT unilateral adr mass & Focus in adr \\
\hline
\end{tabular}

$\mathrm{Adr}=$ adrenal $; \mathrm{T}=$ tumor $\mathrm{CT}$ scan = computed tomography scan $;$ malig = malignant mets $=$ metastases; $\mathrm{L}=1$ left; $\mathrm{R}=$ right; neg = negative; $\mathrm{MIBG}=$ meta-iodobenzylguanidine. 
Table 2. Plasma and urinary catecholamines and hormone profiles.

\begin{tabular}{|c|c|c|c|c|c|c|c|c|c|c|c|}
\hline Patient & $\begin{array}{l}\text { Plasma } \\
\text { NE } \\
(\mathrm{pg} / \mathrm{ml})\end{array}$ & $\begin{array}{l}\text { Plasma } \\
\text { E } \\
(\mathrm{pg} / \mathrm{ml})\end{array}$ & $\begin{array}{l}\text { Urine } \\
\text { NE } \\
(\mu g / 24 h r)\end{array}$ & $\begin{array}{l}\text { Urine } \\
\mathrm{E} \\
(\mu \mathrm{g} / 24 \mathrm{hr})\end{array}$ & $\begin{array}{l}\text { Urine } \\
\text { nmeta } \\
(\mu \mathrm{g} / 24 \mathrm{hr})\end{array}$ & $\begin{array}{l}\text { Urine } \\
\text { meta } \\
(\mu \mathrm{g} / 24 \mathrm{hr})\end{array}$ & $\begin{array}{l}\text { Urine } \\
\text { VMA } \\
(\mu \mathrm{g} / 24 \mathrm{hr})\end{array}$ & $\begin{array}{l}\text { Plasma } \\
\text { SRIF } \\
(\mathrm{pg} / \mathrm{ml})\end{array}$ & $\begin{array}{l}\text { Plasma } \\
\text { substance P } \\
(\mathrm{pg} / \mathrm{ml})\end{array}$ & $\begin{array}{l}\text { Plasma } \\
\text { VIP } \\
(\mathrm{pg} / \mathrm{ml})\end{array}$ & $\begin{array}{l}\text { Plasma } \\
\text { motilin } \\
(\mathrm{pg} / \mathrm{ml})\end{array}$ \\
\hline 1 & & & 162 & 156 & 4,812 & 852 & 8.9 & 134 & 10 & 5 & 170 \\
\hline 2 & 28,837 & 436 & 8,447 & 2,213 & 59,896 & 27 & 113 & 95 & 10 & 36 & 264 \\
\hline 3 & 2,019 & 135 & 454 & 10 & 119 & 8 & 24.8 & 57 & 10 & 5 & 220 \\
\hline 4 & 3,075 & 72 & 222 & 13 & 998 & 56 & 15.5 & 115 & 10 & 5 & 250 \\
\hline 5 & 5,363 & 162 & 1,142 & 0.1 & 183 & 12 & 62 & 83 & 10 & 12 & 146 \\
\hline 6 & 2,327 & 130 & 327 & 14 & 85 & 12 & 23 & 220 & 10 & 5 & 177 \\
\hline 7 & 1,557 & 48 & 128 & 0.1 & 224 & 10 & 9 & 72 & 10 & 5 & 87 \\
\hline 8 & 3,556 & 235 & 86 & 4 & 144 & 7 & 5 & 32 & 80 & 5 & 107 \\
\hline 9 & 2,172 & 795 & 167 & 120 & 2,706 & 471 & 9 & 43 & 10 & 21 & 406 \\
\hline 10 & 1,807 & 44 & 188 & 12 & 108 & 30 & 10 & 68 & 10 & 5 & 97 \\
\hline 11 & 8,345 & 114 & 1,285 & 1 & 87 & 4 & 90 & 276 & 10 & 10 & 65 \\
\hline \multirow[t]{3}{*}{12} & 244,000 & 689 & 2,958 & 380 & 36,763 & 54 & 106 & & & & \\
\hline & 29,939 & 853 & 746 & 78 & 1,151 & 15 & 42 & 139 & 10 & 5 & 313 \\
\hline & & & & & & & & 189 & 10 & 5 & \\
\hline 13 & 6,653 & 98 & 1,178 & 157 & 1,693 & 18 & 62 & 52 & 10 & 5 & 87 \\
\hline 14 & 282 & 90 & 289 & 0.1 & 13 & 10 & 16 & 76 & 10 & 5 & 250 \\
\hline 15 & 3,321 & 47 & 209 & 9 & 735 & 13 & 91 & 60 & 10 & 5 & 196 \\
\hline \multirow[t]{2}{*}{16} & 1,168 & 143 & 439 & 8 & 2,673 & 252 & 31 & 25 & 158 & 5 & 79 \\
\hline & 265 & 57 & & & & & & 137 & 10 & 5 & 201 \\
\hline \multirow[t]{2}{*}{17} & 1,381 & 56 & 1,759 & 56 & 466 & 13 & 123 & & & & \\
\hline & 1,059 & 83 & & & & & & 97 & 10 & 5 & 300 \\
\hline 18 & 5,180 & 261 & & & & & & 101 & 10 & 5 & 449 \\
\hline \multirow[t]{2}{*}{19} & 7,911 & 196 & 1,482 & 6,611 & 902 & 48 & 38 & 72 & 10 & 5 & 281 \\
\hline & 5,420 & 147 & 651 & 55 & 1,296 & 80 & 25 & 71 & 10 & 5 & 159 \\
\hline \multirow[t]{3}{*}{20} & 7,731 & 130 & 763 & 90 & 763 & 18 & 53 & & & & \\
\hline & 14,993 & 254 & & & & & & 27 & 10 & & 54 \\
\hline & & & & & & & & 49 & 10 & 8 & 188 \\
\hline 21 & 589 & 83 & 98 & 33 & 305 & 55 & 7 & 1,184 & 10 & 20 & 232 \\
\hline 22 & 7,427 & 515 & 337 & 43 & 1,729 & 336 & 24 & 112 & 10 & 341 & 139 \\
\hline 23 & 570 & 285 & 169 & 97 & 1,334 & 183 & 82 & 52 & 10 & 55 & 232 \\
\hline 24 & 11,442 & 284 & 683 & 19 & 330 & 23 & 47 & 93 & 10 & 5 & 119 \\
\hline 25 & 255 & 51 & 95 & 7 & 94 & 9 & 7 & 44 & 10 & 18 & 245 \\
\hline 26 & 12,047 & 149 & 702 & 74 & 218 & 21 & 26 & 99 & 10 & 5 & 101 \\
\hline 27 & 3,944 & 1,763 & 461 & 387 & 690 & 746 & 31 & 80 & 10 & 5 & 105 \\
\hline 28 & 4,177 & 2,834 & 221 & 454 & 1,429 & 941 & 121 & 81 & 10 & 11 & \\
\hline 29 & 1,628 & 119 & 81 & 64 & 99 & 15 & 6 & 270 & 10 & 5 & 208 \\
\hline \multirow[t]{3}{*}{30} & 3,397 & 458 & 453 & 158 & 3,968 & 145 & 20 & & & & \\
\hline & 4,068 & 392 & 563 & 34 & 355 & 6 & 31 & 96 & & 22 & 526 \\
\hline & & & 307 & 13 & 1,332 & 103 & 21 & 54 & 10 & 18 & 460 \\
\hline \multirow[t]{3}{*}{31} & 498 & 35 & 69 & 0.3 & 3,826 & 10 & 5 & 1,065 & 10 & 5 & 1,852 \\
\hline & 235 & 71 & 36 & 2 & 2,186 & 36 & 3 & 91 & 10 & 9 & 170 \\
\hline & 307 & 17 & 31 & 4 & 1,500 & 108 & 2 & & & & \\
\hline 32 & 2,091 & 70 & 299 & 7 & 567 & 43 & 21 & & & & \\
\hline 33 & 12,551 & 897 & 2,746 & 14 & 124 & 5 & 150 & 78 & 10 & 13 & 283 \\
\hline \multirow[t]{2}{*}{34} & 157,000 & 361 & 2,496 & 142 & 1,669 & 24 & 75 & 443 & 10 & 7 & 111 \\
\hline & 773 & 50 & 98 & 7 & 163 & 51 & 7 & 85 & 10 & 5 & 124 \\
\hline 35 & 1,477 & 654 & & & & & & 551 & 150 & 10 & 167 \\
\hline 36 & 1,570 & 63 & 70 & 14 & 341 & 37 & 5 & & & & \\
\hline 37 & 3,647 & 79 & 683 & 6 & 323 & 21 & 48 & 71 & 10 & 29 & 194 \\
\hline
\end{tabular}

$\mathrm{NE}=$ norepinephrine $\mathrm{E}=$ epinephrine; nmeta $=$ normetanephrine , meta $=$ metanephrine VMA $=$ vanillylmandelic acid; SRIF = somatostatin; VIP = vasoactive intestinal peptide.

mors, either single or multiple, and 6 had ectopic tumors. Of the 6 ectopic tumors, 5 were paracardiac and 1 was perirenal. This unusual distribution of benign versus malignant pheochromocytomas is based on the fact that these patients were referred from outside centers for localization of the tumors by the MIBG method and thus constitute a unique group of patients. Abnormal elevation of 1 of the 4 hormones was found in $13(62 \%)$ of 21 patients with malignancy, $5(50 \%)$ of 10 of those with intra- 

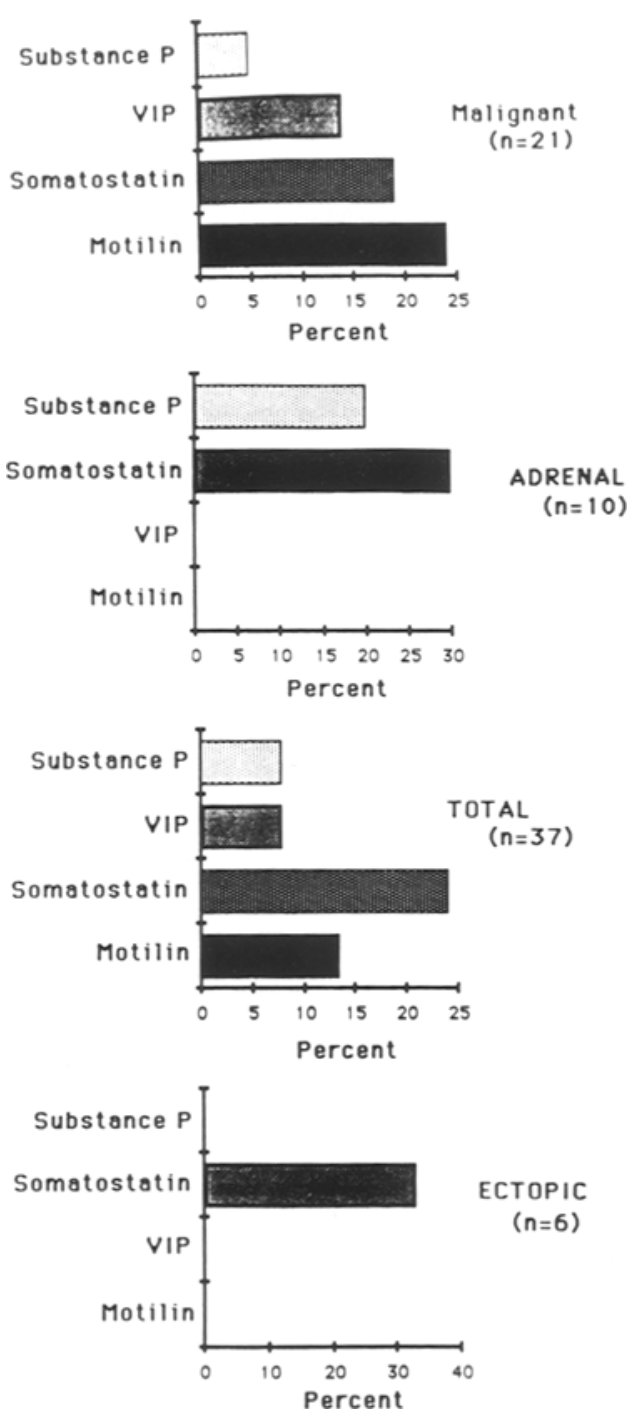

Fig. 1. Bar diagrams indicating the prevalence of abnormally elevated hormone levels in the different types of pheochromocytomas.

adrenal tumors, and $2(33 \%)$ of 6 of those with ectopic tumors. The most commonly raised hormone was somatostatin (24\%), followed by motilin (13.5\%), substance P (8\%), and VIP (8\%) (Fig. 1). In 2 patients there was elevation of 2 hormones. One patient had high levels of motilin and SS and the other, substance $P$ and SS. Only in 1 patient with a malignant tumor was there elevation of all 4 peptides and, furthermore, only in malignant tumor patients did the elevation of 2 peptides coexist. The overall prevalence of abnormal elevation of gastroenteropancreatic (GEP) hormones was 20 (54\%) of 37 patients. Although in the ectopic tumors there was elevation only of SS, the difference between ectopic, intra-adrenal, and malignant tumors was not significant. There was no correlation

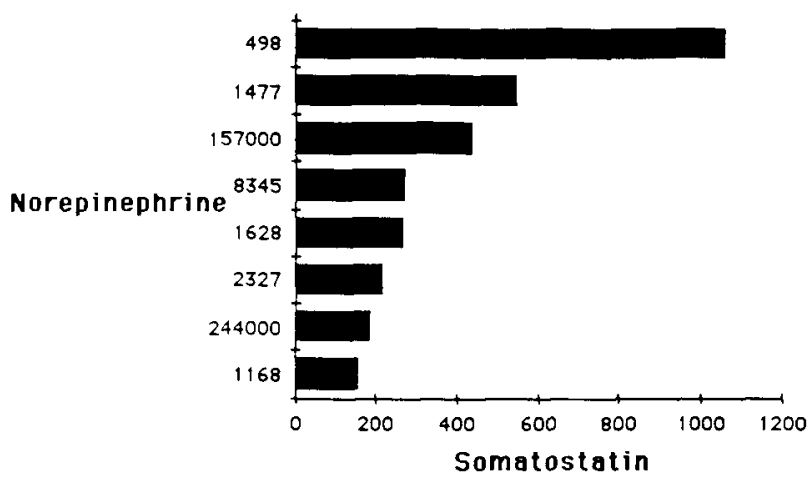

Fig. 2. Bar diagrams show the lack of correlation between norepinephrine levels and somatostatin. This also applied to the other hormones measured.

found between any of the measurements of catecholamines and the degree or extent of elevation of the GEP hormones (Fig. 2).

Case I

J.S. (No. 35, Table 1) was a 56-year-old white male who presented to another hospital with pain and discomfort secondary to a right suprarenal tumor, the nature of which was not immediately apparent. The lesion was hypervascular and parasitized the blood supply from the right renal artery. In addition, he had pain from pathologic fractures of the neck of the right humerus and the shaft of the left femur. A biopsy from the femoral lesion was interpreted as transitional carcinoma. He was also found to be diabetic and hypertensive. He had been treated with alpha-methyldopa, propranolol, hydralazine, and chlorpropamide.

He was admitted for chemotherapy but developed an attack of acute pallor, marked diaphoresis, epigastric discomfort, and chest pain with diffuse wheezing. Hypertension was prominent. His subsequent course was marked by severe intractable dyspnea, wheezing, and hypertension. The bronchospasm was unresponsive to steroids, aminophylline, atropine, prostaglandin inhibitors, $\mathrm{H}_{1}$ and $\mathrm{H}_{2}$ antagonists, or beta adrenergic agonists. A persistently elevated pulmonary wedge pressure of $35 \mathrm{~mm}$ $\mathrm{Hg}$ was observed in the absence of left heart failure, fluid overload, or pulmonary emboli and required positive pressure ventilation.

Review of the histologic features with the use of special silver stains revealed the tumor to be of neuroendocrine origin. There was intense argyrophyllia with Grimelius silver stain. Immunohistochemical tests for insulin, glucagon, pancreatic polypeptide, and calcitonin were negative. Plasma catecholamines were markedly elevated (epinephrine $654 \mathrm{pg} / \mathrm{ml}$, norepinephrine $1,477 \mathrm{pg} / \mathrm{ml}) ; 5$ - 


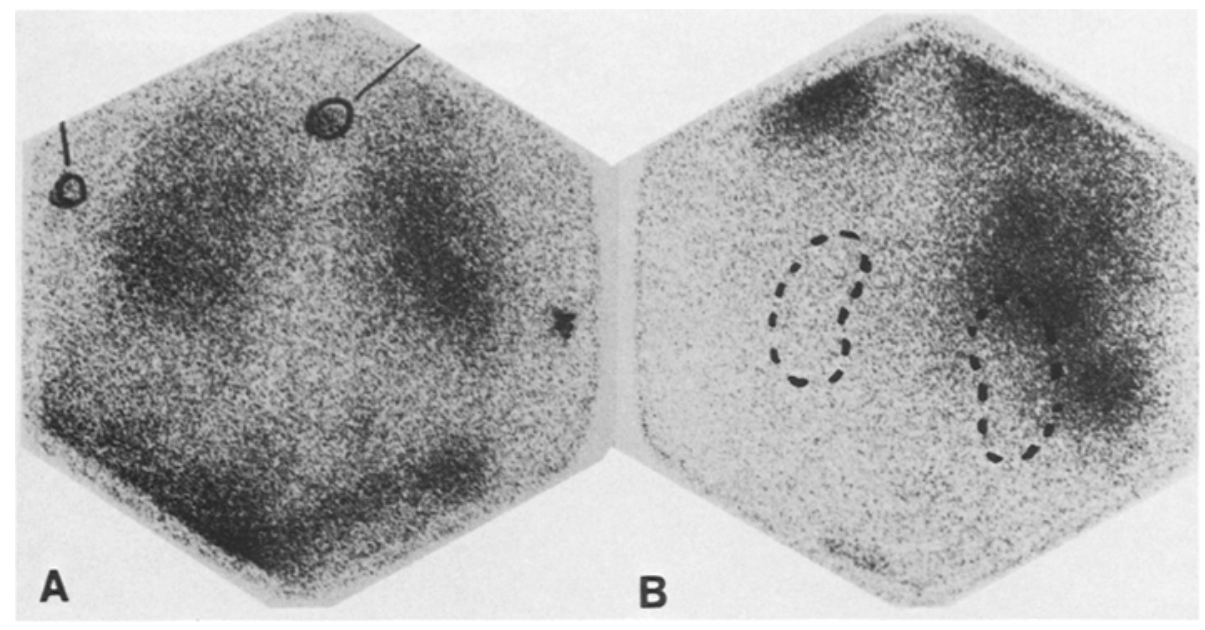

Fig. 3A. Patient 1: ${ }^{131}$ I-MIBG scintigraphy shows bilateral diffuse uptake in both lung fields. The abdominal tumor can be seen in the lower edge of the field. B. View of the large suprarenal mass in the posterior abdomen and the diffuse uptake in the lower lung fields. The kidneys have been outlined as reference markers.

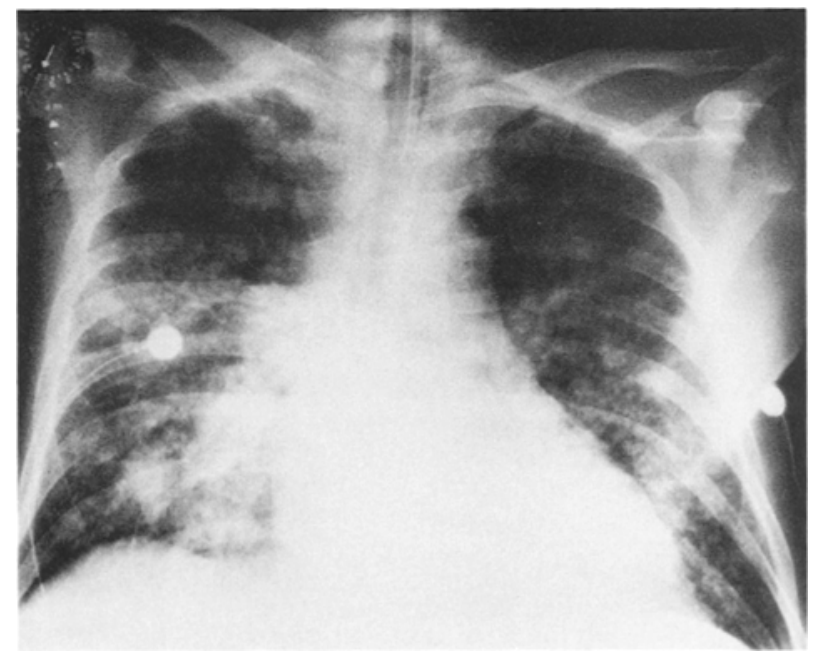

Fig. 4. Patient 1: Chest $\mathrm{x}$-ray shows diffuse nodularreticular pattern throughout both lung fields due to multiple metastases.

HIAA was normal and calcitonin was slightly raised $(0.58$ and $0.49 \mathrm{ng} / \mathrm{ml})$.

At this point it was felt that the patient was suffering from bronchospastic and vasospastic effects of a neurohumoral factor secreted by the tumor. Somastostatin was markedly raised (551 $\mathrm{pg} / \mathrm{ml})$ as was substance $P(150 \mathrm{pg} / \mathrm{ml})$. ${ }^{131} \mathrm{I}-\mathrm{MIBG}$ scintigraphy revealed areas of uptake in the right suprarenal region with multiple bony and lung metastases (Fig. 3). Pulmonary infiltrates were progressive and thought to be due to metastases (Fig. 4). $\mathrm{He}$ died as a consequence of intractable bronchospasm and hypoxia with terminal bronchopneumonia. Autopsy was refused.

We believe this to be a case in which the secretion of both catecholamines and the vaso- and broncho-constrictive peptides contributed to the hypertension, diabetes, pallor, diaphoresis, bronchospasm, and vasoconstriction.

\section{Case 2}

C.C. (No. 11, Table 1) was a 68-year-old white female, who in 1976 developed watery diarrhea and hypokalemia which persisted despite fasting. One year later she had a pathologic fracture of the right pubic ramus. A bone scan revealed metastases in the ribs, sternum, and pelvis. Angiography revealed a $10 \times 9 \times 7 \mathrm{~cm}$ hypervascular mass in the right adrenal region. Preoperative blood samples demonstrated high levels of VIP and a transtumor gradient was shown at surgery when the tumor and the right kidney were removed. The tumor had all the histologic features of a pheochromocytoma. After surgery the diarrhea and hypokalemia resolved and the VIP level returned to normal, although catecholamine levels remained elevated (Table 2). In 1981, a $5 \times 5 \mathrm{~cm}$ para-aortic mass was resected which was histologically a mixed pheochromocytoma-ganglioneuroma. Prior to referral to the University of Michigan in 1982 she was noted to have a $2-\mathrm{cm}$ para-aortic mass by ultrasound and $\mathrm{CT}$ and bone scan showed metastases to the occiput (Fig. 5). ${ }^{131}$ I-MIBG scintigraphy showed abnormal foci of uptake in the occiput, superior mediastinum, upper abdomen, periaortic region, and lower abdomen in the region of the aortic bifurcation. Plasma and urinary catecholamines were significantly elevated (Table 2).

This is an example in which a pheochromocytoma caused the Verner-Morrison syndrome, but subsequent recurrences did not elaborate VIP. This heterogeneity of primary and secondary endocrine tumors is well recognized. 

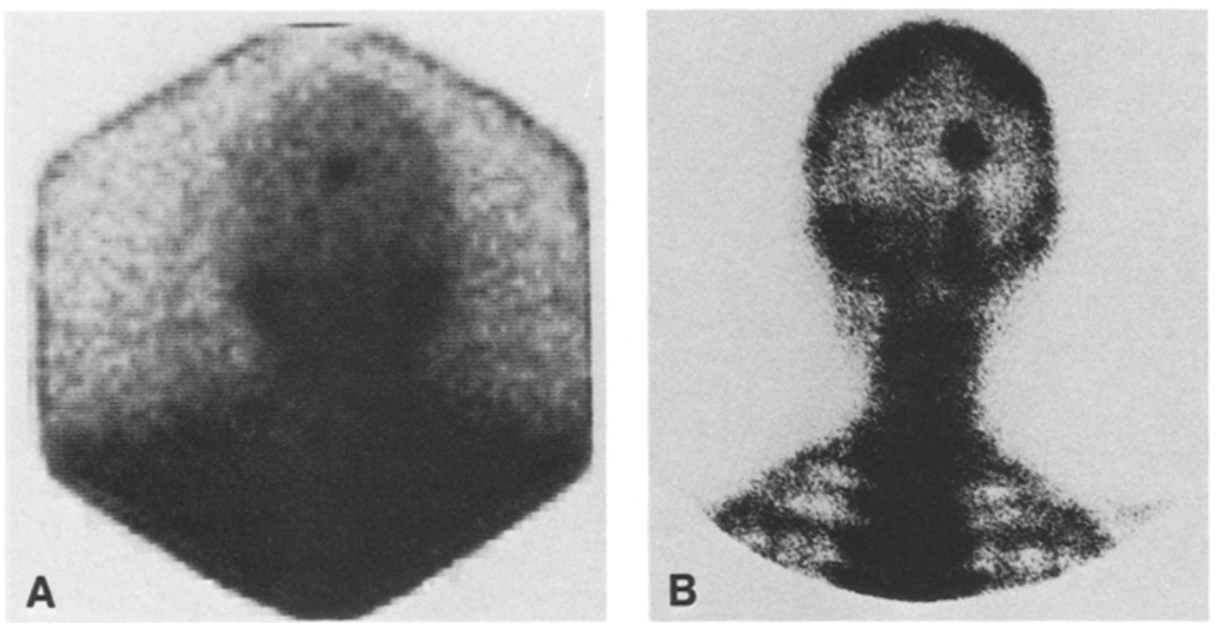

Fig. 5. Patient 2: Occipital metastasis from a pheochromocytoma.

A. ${ }^{131}$ I-MIBG scintigram.

B. ${ }^{99} \mathrm{Tc}$ MDP bone scan.

\section{Discussion}

The majority of the highly diverse clinical manifestations of the pheochromocytoma syndrome can be ascribed to hypercatecholaminemia. This is certainly true of hypertension, tachycardia palpitations, sweating, tremor, and headache. Other factors may contribute to the presence of other symptoms, for instance, hypotension (which may be due to epinephrine and perhaps dopamine as well as other postulated neurohumors), glucose intolerance and diabetes, flushing, diarrhea, and constipation. Certainly, the unusual manifestations of diarrhea and bronchospasm demonstrated by the 2 example cases are hard to ascribe to catecholamines alone. Thus, the role of brain-gut neurohumoral peptides acting either alone or in combination with catecholamines and/or other biogenic amines (e.g., serotonin) need to be considered.

The severity of symptoms (including hypertension) are only poorly related to the actual levels of catecholamines. In examining brain-gut peptides that might be hypersecreted in pheochromocytoma and that might give rise to symptomology, the following candidates were considered:

1. Vasoactive intestinal peptide (VIP) is found in the neurons of the intrinsic nervous system of the gut and the adrenal medulla [25, 26]. It has been reported to be present in pheochromocytomas [27-36], an observation we have confirmed. Hypersecretion of VIP may contribute to diarrhea (sometimes reaching full-blown Verner-Morrison syndrome [37]), hypotension, and flushing in certain cases of pheochromocytoma [28-31, 34, 35] as in 1 of our patients. In other instances, moderate elevations may be asymptomatic as was the case in 2 of 3 patients with raised VIP levels.

2. Somatostatin (SS) is a neuropeptide with remarkably wide distribution [38]. A clinical syn- drome comprising diabetes, diarrhea or steatorrhea, achlorhydria, and biliary disease has been reported in association with somatostatinomas [39-42]. Its presence has been observed in pheochromocytomas [43], and was the most common abnormality in our series. Hypersecretion of the neurohumoral peptide may contribute to the glucose intolerance, constipation and/or diarrhea, disordered gut motility, and malabsorption of fats due to suppression of pancreatic exocrine function.

3. Motilin is a peptide hormone found to be present in the enterochromaffin cell of the distal small gut [42-45]. Its major physiologic function is to promote emptying of the gut in the interdigestive period by stimulating the interdigestive myoelectric complex. Hypersecretion along with serotonin is frequent in carcinoid tumors, [21, 42-45] another lesion derived from the APUD system. The demonstration of elevated levels of motilin in pheochromocytoma patients is apparently a new observation. Excessively raised levels of motilin may be associated with diarrhea but elevations have been observed as a secondary (compensatory?) phenomenon associated with autonomic neuropathy and paralysis of the stomach and small gut [46]. Thus, extraction of tumors and demonstration of synthesis and secretion of the peptide is needed to implicate fully the pheochromocytoma per se in the production of this peptide.

4. Substance $P$ is a neuropeptide first isolated from the spinal cord by von Euler in 1931 [47] and has since shown to be widely distributed in the central nervous system, including the substantia nigra, and brain stem, as well as the dorsal root ganglia and widely throughout the gut. In the gut the peptide is found in both the enterochromaffin cells and neurones of the myenteric plexus [48]. The peptide is also found in autonomic ganglia and may subserve a function in the sympathetic nervous 
system [49]. It has been found to increase the catechol synthesizing activity of the enzyme tyrosine-hydroxylase and to initiate the slow excitatory postsynaptic potential [50]. The peptide is a potent vasodilator [51] and may contribute to the flushing and hypotension that occur in pheochromocytoma. It is also a potent vasoconstrictor of bronchial and gut smooth muscle [51] and may cause bronchospasm and diarrhea [52]. Reports have implicated elevated levels of substance P to be associated with episodic wheezing, diarrhea, and flushing in cases of carcinoid syndrome $[21,53,54]$ and medullary carcinoma of the thyroid [55]. The symptom complex in our first example case may have been a result of excess production of substance $P$.

5. Chromogranin and neuron-specific enolase are markers for tumors derived from the APUD system $[23,24,56]$. These features can be detected in tissue by immunohistochemistry as was done in a subgroup of patients in this series or may be present in abnormal concentrations in plasma of patients harboring malignant metastatic tumors. There appears to be no obvious clinical pathophysiological correlation with the presence of high circulating levels of these substances.

There are other peptide neurohormones that may occur in pheochromocytoma but were not examined in this study. These substances are numerous but 2 require specific mention. Since their initial localization in the central nervous system, endogenous opiate peptides have been shown to be widely present in the gut and in the sympathoadrenomedullary system [57]. Peptides of the proopiomelanocortin family appear to be secreted in various concentrations and the clinical syndrome of ectopic adrenocorticotropic hormone (ACTH) with Cushing's syndrome has been observed in pheochromocytoma as well [58]. Unfortunately, we did not measure levels of opiates in tumor or in peripheral plasma. The compound met-enkephalin is especially prominent in pheochromocytomas and may contribute to the constipation which may be severe in this disease [59-65].

Neuropeptide $Y$ has wide central nervous system distribution and also occurs in the heart, especially in the region of the atrioventricular node and may affect cardiac rate and rhythm [62-67]. In addition, the compound has profound vasoconstrictor properties and occurs in pheochromocytoma in which it may contribute to the vasoconstriction $[68,69]$.

Other factors noted to occur with pheochromocytoma include calcitonin, neurotensin [70], gastrin [71], and a hypercalcemic factor [72], but their role in the clinical symptomatology has not been elucidated.

The peptide neurohormones described above may interact with each other and/or biogenic
Table 3. Symptoms and signs in pheochromocytoma patients resulting from interactions with various peptide neurohormones.

\begin{tabular}{|c|c|}
\hline Symptom & Hormone \\
\hline Flushing & VIP and substance $P$ \\
\hline Constipation & $\begin{array}{l}\text { Catecholamines, opiate peptides, } \\
\text { and somatostatin }\end{array}$ \\
\hline Diarrhea & $\begin{array}{l}\text { Serotonin, VIP, motilin, and } \\
\text { somatostatin }\end{array}$ \\
\hline Glucose intolerance & Catecholamines and somatostatin \\
\hline $\begin{array}{l}\text { Pallor and } \\
\text { vasoconstriction }\end{array}$ & $\begin{array}{l}\text { Catecholamines and } \\
\text { neuropeptide } \mathrm{Y}\end{array}$ \\
\hline True polycythemia & Erythroprotein-like factor [74] \\
\hline Hypercalcemia & $\begin{array}{l}\text { Parathyroid hormone-like factor } \\
\text { and VIP [72] }\end{array}$ \\
\hline
\end{tabular}

amines to produce certain symptoms and signs in the pheochromocytoma syndrome [73]. These are outlined in Table 3.

A further consideration is that the hypercatecholaminemia may through pharmacological and physiological effects influence the concentrations of circulating neurohumoral brain-gut peptides. This seems to be true for hypergastrinemia, which has been observed in patients with pheochromocytomas [71]. Absolute certainty as to the tumoral production of these peptides would require: demonstration of elevated concentrations in the peripheral circulation; concentration of a transtumoral gradient in the arterial and venous levels of the peptide; elevated concentrations of the peptide within the tumor (which may not occur if storage capacity is limited), and an increase of gene product transcription in the tumor (e.g., messenger RNA). It is only very seldom possible to achieve this level of rigor.

Examination of the data presented in this article and in the literature leads inexorably to the conclusion that pheochromocytomas do secrete brain-gut neurohumoral peptides and that these may contribute to the diverse spectrum of clinical manifestations that can accompany this tumor.

\section{Résumé}

Les phéochromocytomes sont généralement déceléspar les effets dûs à la surproduction de catécholamines, mais certains troubles ne peuvent être attribués à ce phénomène et relèvent peut être de l'action de peptides vasoactifs. Les auteurs se sont donc attachés à doser dans le sang le VIP, la substance P, la somatostatine (SS), et la motiline. Ces dosages furent pratiqués 50 fois chez 37 malades porteurs de phéochromocytomes: 21 malins, 10 bénins et 6 ectopiques ( 5 paracardiaque et 1 péri-rénal). Les taux des hormones furent considérés comme élevés lorsque leur niveau fut 
supérieur à plus de 3 fois le taux de 52 sujets sains. Sur les 37 malades $20(54 \%)$ présentaient un excès d'une ou de plusieurs hormones digestives. L'anomalie constatée la plus fréquente fut l'élévation de la SS ( 9 fois sur 37 soit 24\%). Ajoutée à ce fait fut l'élévation de la VIP chez 3 sujets $(8 \%)$, de la motiline chez 5 (13.5\%) et de la substance P chez 3 (8\%). Les phéochromocytomes bénins surrénaliens présentaient à la fois une élévation du taux de la SS et de la substance P. Les phéochromocytomes ectopiques en revanche présentaient seulement une élévation de la SS. Les phéochromocytomes malins pouvaient sécréter les 4 peptides ou plus d'un chez le même malade. En conclusion les phéochromocytomes peuvent secréter de multiples peptides vasoactifs et plus particulièrement lorsqu'ils sont malins. La SS est la substance qui est la plus souvent secrétée et elle est trouvée dans les tumeurs bénignes surrénaliennes ou ectopiques. Si plus d'une de ces substances est produite en excès les risques de malignité de la tumeur sont significativement plus importants.

\section{Resumen}

Los feocromocitomas generalmente son diagnosticados por los efectos del exceso de producción de catecolaminas pero hay características clínicas que no pueden ser atribuidas al exceso de catecolaminas y que pueden ser más bien manifestación de péptidos vasoactivos. Hemos establecido los niveles sanguíneos del péptido intestinal vasoactivo (VIP), de la sustancia P, de la somatostatina (SS), y de la motilina en 50 determinaciones en 37 pacientes con feocromocitomas; 21 malignos, 10 benignos intra-adrenales, y 6 ectópicos $(5$ paracardiales y 1 perirrenal). Se consideró que los niveles hormonales estaban elevados cuando el nivel era de más de 3 de desviación estandar sobre el valor promedio en 52 individuos normales. De 37 pacientes, $20(54 \%)$ presentaron un valor anormal en 1 o más determinaciones del nivel de hormonas intestinales. La anormalidad más común fue la elevación de la SS en 9/37 (24\%). Además de esto, sinembargo, otros $3(8 \%)$ presentaban elevación de VIP, 5 (13.5\%) elevación de sustancia P. Los adenomas suprarrenales benignos exhibieron niveles elevados de SS y de sustancia P. Los feocromocitomas ectópicos demostraron producción sólo de SS además de catecolaminas, pero los feocromocitomas malignos demostraron ser capaces de secretar todos los 4 péptidos, y más de 1 en el mismo paciente. Hemos llegado a la conclusión de que los feocromocitomas pueden secretar múltiples peptidos vasoactivos y que ésto tiende a ocurrir cuando son malignos. La SS es el péptido más frecuentemente secretado y se lo encuentra en los tumores suprarrenales benigno y ectópico (paracardiacos). Si se encuentran niveles elevados de más de 1 péptido, la posibilidad de malignidad aparece significativamente aumentada.

\section{Acknowledgments}

Supported in part by the following grants: NIAMDD 5P60 AM 20575, NCI 09015, DHEW 3M01 RR00042-22-S1 CLR, NIH R01 AM 21477, and AM R01 27077, R01 FD-01257 and the Nuclear Medicine Research Fund. Shapiro is the recipient of an NIH Clinical Associate Physician Award (DHEW 3M01 RR00042-22-S1 CLR).

The authors wish to thank all those physicians who referred patients for study as well as the fellows, house officers, technicians and nursing staff of the Division of Nuclear Medicine and the Clinical Research Center, who made this possible. Dr. Thomas Mangner and Holly Anderson-Davis are thanked for the manufacture of ${ }^{131}$ I-MIBG and the Phoenix Memorial Laboratory for the use of their radiochemistry facilities.

\section{References}

1. Sjoerdsma, A., Engleman, K., Waldmann, T.A., Cooperman, L.M., Hammond, W.G.: Pheochromocytoma: Current concepts of diagnosis and treatment. Ann. Intern. Med. 65:1302, 1966

2. Manger, W.M., Gifford, R.W.: Hypertension secondary to pheochromocytoma. Bull. N.Y. Acad. Med. $58: 139,1982$

3. Freier, D.T., Eckhauser, F.E., Harrison, F.S.: Pheochromocytoma: A persistently problematic and still potentially lethal disease. Arch. Surg. 115:388, 1980

4. VonEuler, U.S., Lishajko, F.: The estimation of catecholamines in the urine. Acta Physiol. Scand. $45: 122,1959$

5. Bravo, E.L., Tarazi, R.C., Gifford, R.W., Stewart, B.H.: Circulating and urinary catecholamines in pheochromocytoma: Diagnostic and pathophysiologic implications. N. Engl. J. Med. 301:682, 1979

6. Freier, D.T., Harrison, T.S.: Rigorous biochemical criteria for the diagnosis of pheochromocytoma. J. Surg. Res. 14:1177, 1973

7. Pearse, A.G.E.: The cytochemistry and ultrastructure of polypeptide hormone-producing cells of the APUD series and the embryologic physiologic and pathologic implications of the concept. J. Histochem. Cytochem. 17:303, 1969

8. Andrew, A.: The APUD concept: Where has it led us? Br. Med. Bull. 38:221, 1982

9. Bolande, R.P.: The neurocristopathies: A unifying concept of disease arising in neural crest maldevelopment. Hum. Pathol. 5:409, 1974

10. Andrew, A.: An experimental investigation into the possible neural crest origin of pancreatic APUD (islet) cells. J. Embryol. Exp. Morphol. 35:577, 1976

11. Schultzberg, M., Hokfelt, T., Lundberg, J.M.: Coexistence of chemical transmitters and peptides in the 
central and peripheral nervous systems. Br. Med. Bull. 38:309, 1982

12. Kogut, M.D., Kaplan, S.A.: Systemic manifestations of neurogenic tumors. J. Pediatr. 60:694, 1962

13. Sizemore, G.W., Huntyer, H., Carney, J.A.: Multiple endocrine neoplasia type II. Clin. Endocrinol. Metab. 9:299, 1980

14. McEwan, A.J., Shapiro, B., Sisson, J.C., Beierwaltes, W.H., Ackery, D.M.: Radio-iodobenzylguanidine for the scintigraphic location and therapy of adrenergic tumors. Sem. Nucl. Med. 15:132, 1985

15. Shapiro, B., Copp, J.E., Sisson, J.C., Eyre, P.L., Wallis, J., Beierwaltes, W.H.: ${ }^{131}$ I-metaiodobenzylguanidine for the locating of suspected pheochromocytoma: Experience in 400 cases (441 studies). J. Nucl. Med. 26:576, 1985

16. Nakajo, M., Shapiro, B., Copp, J.E., Kalff, V., Gross, M.D., Sisson, J.C., Beierwaltes, W.H.: The normal and abnormal distribution of the adrenomedullary imaging agent $\mathrm{m}$-[I-131]Iodobenzylguanidine (I-131-MIBG) in man: Evaluation by scintigraphy. J. Nucl. Med. 24:672, 1983

17. Peuler, J.D., Johnson, G.A.: Simultaneous single isotope radioenzymatic assay of plasma norepinephrine, epinephrine and dopamine. Life Sci. 21:625, 1971

18. Vinik, A.I., Levitt, N., Pimstone, B.L., Wagner, L.: Peripheral plasma somatostatin-like immunoreactivity responses to mixed meals and insulin-hypoglycemia in healthy subjects and in non-insulin dependent diabetics. J. Clin. Endocrinol. Metab. 52:330, 1980

19. Funakoshi, A., Glowniak, J., Owyang, C., Vinik, A.I.: Evidence for cholinergic and vagal non-cholinergic mechanisms modulating plasma motilin-like immunoreactivity. J. Clin. Endocrinol. Metab. $54: 1129,1982$

20. Wesley, J.R., Vinik, A.I., O'Dorisio, T.M., Glaser, B., Fink, A.: A new syndrome of symptomatic mastocytoma producing vasoactive intestinal peptide (VIP). Gastroenterology 82:963, 1982

21. Strodel, W., Vinik, A.I., Jaffe, B.M., Eckhauser, F.E., Thompson, N.W.: Substance P in localization of carcinoid tumors. J. Surg. Oncol. 27:106, 1984

22. Sternberger, L.A., Hardy, P.H., Jr., Cuculis, J.J., Meyer, H.G.: The unlabeled antibody enzyme method of immunohistochemistry: Preparation and properties of soluble antigen-antibody complex (horseradish peroxidase-antihorseradish peroxidase) and its use in identification of spirochetes. J. Histochem. Cytochem. 18:315, 1970

23. Simpson, S., Vinik, A.I., Marangos, P.J., Lloyd, R.V.: Immunhistochemical localization of neuronespecific enolase in gastro-enteropancreatic tumors. Correlation with tissue and serum levels of neuronspecific enolase. Cancer 54:1364, 1984

24. O'Connor, D.T., Bernstein, K.N.: Radioimmunoassay of chromogranin $A$ in plasma as a measure of exocytotic sympathoadrenal activity in normal subjects and patients with pheochromocytoma. N. Engl. J. Med. 311:764, 1984

25. Said, S.I.: Vasoactive intestinal peptide (VIP): Isolation, distribution, biological actions, structure-function relationships, and possible functions. In Gastrointestinal Hormones, G.B.J. Glass, editor. New York, Raven Press, 1980, pp. 245-274
26. Fahrenkrug, J., Emson, P.C.: Vasoactive intestinal polypeptide: Functional aspects. Br. Med. Bull. $38: 265,1982$

27. Faurel, J.P., Bernard, P., Saigot, T.H., Bousquet, O., Sarrazin, A.: Pheochromocytome secretant du vaso-active intestinal peptide et de la somatostaineune observation. Nouv. Presse Med. 2:1483, 1982

28. Rosenstein, B.J., Engleman, K.: Diarrhea in a child with a catecholamine-secreting ganglioneuroma. J. Pediatr. 63:217, 1963

29. Loehry, C.A., Kinghon, J.G.C., Wharwell, P.J.: Watery diarrhea and hypokaliemia associated with a pheochromocytoma. Postgrad. Med. J. 51:419, 1975

30. Matta, M.K., Prarok, J.J., Trimpi, H.D., Sheets, J.A., Stasik, J.J., Khuhdadani, I.T.: WDHA syndrome caused by pheochromocytoma. Dis. Colon Rectum 21:297, 1978

31. Trump, D.L., Livingston, J.N., Baylin, S.B.: Watery diarrhea syndrome in an adult with ganglioneuromapheochromocytoma. Cancer 40:1526, 1977

32. Viale, G., Dell'orto, O., Moro, E., Cozzaglio, L., Coggi, G.: Vasoactive intestinal polypeptide, somatostatin and calcitonin-producing adrenal pheochromocytoma associated with the watery diarrhea (WDHH) syndrome: First case report with immunohistochemical findings. Cancer 55:1099, 1985

33. Long, R.G., Bryant, M.G., Mitchell, S.J., Adrian, T.E., Polak, J.M., Bloom, R.S.: Clinicopathological study of pancreatic and ganglioneuroblastoma tumours secreting vasoactive intestinal polypeptide (vipomas). Br. Med. J. 282:1767, 1981

34. Trump, D.L., Livingston, J.N., Baylin, S.B.: Watery diarrhea syndrome in an adult with ganglioneuromapheochromocytoma: Identification of vasoactive intestinal peptide, calcitonin, and catecholamines and assessment of their biologic activity. Cancer 40:1526, 1977

35. Loehry, C.A., Kingham, J.C.G., Whorwell, P.J.: Watery diarrhea and hypokalaemia associated with a pheochromocytoma. Postgrad. Med. J. 51:416, 1975

36. Pais, S.O.: Angiographic demonstration of a vasoactive intestinal polypeptide-secreting pheochromocytoma in a patient with WDHA syndrome. A.J.R. 130:172, 1978

37. Verner, J.V., Morrison, A.B.: Endocrine pancreatic islet disease with diarrhea: Report of a case due to diffuse hyperplasia and nonbeta islet tissue with a review of 54 additional cases. Arch. Intern. Med. $133: 492,1974$

38. Vinik, A.I., Gaginella, T., O’Dorisio, T., Shapiro, B., Wagner, L.: The distribution and characterization of somatostatin-like immunoreactivity in epithelial cells, submucosa and muscle of the rat stomach and intestine. Endocrinology 109:1921, 1981

39. Larsson, L.-I., Hirsch, M.A., Holst, J.J., Ingemansson, S., Kühl, C., Lindkaer Jensen, S., Lundqvist, G., Rehfeld, J.F., Schwartz, T.W.: Pancreatic somatostatinoma clinical features and physiologic implications. Lancet $1: 666,1977$

40. Ganda, O.P., Weir, G.C., Soeldner, J.S., Legg, M.A., Chick, W.L., Patel, Y.C., Ebeid, A.M., Gabbay, K.H., Reichlin, S.: Somatostatinoma: A somatostatin containing tumor of the pancreas. N. Engl. J. Med. 296:963, 1977

41. Krejs, G.J., Orci, L., Conlon, J.M., Ravazzola, M., 
Davis, G.R., Raskin, P., Collins, S.M., McCarthy, D.M., Baetens, D., Rubenstein, A., Aldor, T.A.M., Unger, R.H.: Somatostatinoma syndrome (biochemical, morphologic and clinical features). N. Engl. J. Med. 301:285, 1979

42. Vinik, A.I., Strodel, W., Lloyd, R.V., Thompson, N.W.: Unusual gastro-enteropancreatic tumors and their hormones. In Endocrine Surgery Update, N.W. Thompson, A.I. Vinik, editors. New York, Grune and Stratton, 1983, pp. 293-320

43. Lundberg, J.M., Hamberger, B., Schyltzberg, M., Hokfelt, T., Granberg, P.-O., Efendic, S., Terenius, L., Goldstein, M., Luft, R.: Enkephalin and somatostatin-like immunoreactivities in human adrenal medulla and pheochromocytomas. Proc. Natl. Acad. Sci. U.S.A. 76:4079, 1979

44. Sano, T., Saito, H., Inaba, H., Hizawa, K., Saito, S., Yamanoi, A., Mizunuma, Y., Matsumura, M., Yuasa, M., Hiraishi, K.: Immunoreactive somatostatin and vasoactive intestinal polypeptide in adrenal pheochromocytoma: An immunochemical and ultrastructural study. Cancer 52:282, 1983

45. Vinik, A.I., Strodel, W.E., O'Dorisio, T.M.: Endocrine tumors of the gastroenteropancreatic axis. In Diagnosis and management of Endocrine-related Tumors, R.J. Santen, A. Manni, editors. Boston, Martinus Nijhoff Publishers, 1984, pp. 235-304

46. Glowniak, J., Funakoshi, A., Owyang, C., Vinik, A.I.: Plasma Motilin-like immunoreactivity in insulin-dependent diabetics (IDDM) with and without autonomic neuropathy and in vagotomized subjects. Abstract ADA, June 15-19, 1981

47. von Euler, U.S., Gaddum, J.H.: An unidentified depressor substance in certain tissue extracts. J. Physiol. 72:74, 1931

48. Sundler, F., Håkanson, R., Larsson, L.-T.: Substance $P$ in the Gut: An immunochemical and immunohistochemical study of its distribution and development. In Substance P, U.S. von Euler, B. Pernow, editors. New York, Raven Press, 1977, pp. 59-65

49. Jiang, Z.G., Dun, N.J., Karczmar, A.G.: Substance $\mathrm{P}$ : A putative sensory transmitter in mammalian autonomic ganglia. Science $217: 739,1982$

50. Kesller, J.A., Adler, J.E., Black, I.B.: Substance P and somatostatin regulate sympathetic noradrenergic function. Science $221: 1059,1983$

51. Eklund, B., Jogestrand, T., Pernow, B.: Effect of substance $P$ on resistance and capacitance vessels in the human forearm. In Substance P, U.S. von Euler, B. Pernow, editors. New York, Raven Press, 1977, pp. 275-285

52. Yau, W.M.: Effect of substance $P$ on intestinal muscle. Gastroenterology 74:228, 1978

53. Skrabanek, P., Dervan, P., Cannon, D., Powell, D.: Substance $P$ in ovarian carcinoid. J. Clin. Pathol. $33: 160,1980$

54. Ratzenhofer, M., Gamse, R., Höfler, H., Auböck, L., Popper, H., Pohl, P., Lembeck, F.: Substance P in the argentaffin carcinoid of the cecum: Biochemical and biological characterization. Virchows Arch. 392:21, 1981

55. Skrabanek, P., Cannon, D., Dempsey, J., Kirrane, J., Neligan, M., Powell, D.: Substance P in medullary carcinoma of the thyroid. Experientia 35:1259, 1979
56. Landsberg, L.: Editorial. N. Eng. J. Med. 311:794, 1984

57. Viveros, O.H., Diliberto, E.J., Hazum, E., Chang, K.J.: Opiate-like materials in the adrenal medulla: Evidence for storage and secretion with catecholamines. Mol. Pharmacol. 16:1101, 1979

58. Luton, J.P., Thieblot, P., Bricaire, H.: Association syndrome de Cushing-pheochromocytome. Nouv. Presse Med. 6:4053, 1977

59. Linnoila, R.I., DiAugustine, R.P., Hervonen, A., Miller, R.J.: Distribution of $\left(\mathrm{met}^{5}\right)$ - and $\left(\mathrm{Leu}^{5}\right)$-enkephalin, vasoactive intestinal polypeptide, and substance P-like immunoreactivities in human adrenal glands. Neuroscience $5: 2247,1980$

60. Clement-Jones, V., Corder, R., Lowry, P.J.: Isolation of human met-enkephalin and two groups of putative precursors ( $2 \mathrm{~K}$-pro-met-enkephalin) from an adrenal medullary tumour. Biochem. Biophys. Res. Commun. 95:665, 1980

61. Corder, R., Lowry, P.J., Emson, P.C., Gaillard, R.C.: Neuropeptide $Y$, a vasoconstrictor peptide, circulates in patients with adrenal medullary phaeochromocytoma. Proc. 7th Intl. Congr. Endocrin., Quebec City, Canada, July 1-7, 1984, Princeton, Excerpta Medical, 1984, Abstract 948, p. 734

62. Matsuo, H., Miyata, A., Mizuno, K.: Novel Cterminally amidated opical peptide in human phaeochromocytoma tumors. Nature 305:721, 1983

63. Bertagna, X., Pique, K.L., Ochoa, C., Luton, J.P., Bricaire, H., Serin, D., Girard, F.: Simultaneous measurement of beta-endorphin, lipotrophins and met-enkephalin in phaeochromocytoma. Acta Endocrinol. 1091:72, 1982

64. Livett, B.G., Dean, D.M., Whelan, L.G., Undenfriend, S., Rossier, J.: Co-release of enkephalin and catecholamines from cultured adrenal chromaffin cells. Nature 289:317, 1981

65. Giraud, P., Oliver, C., Conte-Devois, B., Gillioz, P., Lissitzky, J.C., Orlando, M., Boudouresque, F., Henry, F., Nonneau, H.P., Lebreuil, G.: Mise en evidence de methionine et leucine enkephaline dans deux pheochromocytomes. Nouv. Presse Med. 9:1641, 1980

66. Gu, J., Polak, J.M., Adrian, T.E., Allen, J.M., Tatemoto, K., Bloom, S.R.: Neuropeptide tyrosine (NPY)-a major cardiac neuropeptide. Lancet $1: 1008,1983$

67. Varndell, I.M., Polak, J.M., Allen, J.M., Terenghi, G., Bloom, S.R.: Neuropeptide tyrosine (NPY) immunoreactivity in norepinephrine containing cells and nerves of the mammalian adrenal gland. Endocrinology $114: 1460,1984$

68. Adrian, T.E., Terenghi, G., Bacarese-Hamilton, A.J., Brown, M.J., Polak, J.M., Bloom, S.R.: Neuropeptide $\mathrm{Y}$ in phaeochromocytomas and ganglioneuroblastomas. Lancet 2:540, 1983

69. Tischler, A.S., Allen, J.M., Costopoulos, D., Bloom, S.R.: Increased content of neuropeptide $Y$ in human pheochromocytoma cell cultures. J. Clin. Endocrinol. Metab. 61:303, 1985

70. Tischler, A.S., Lee, Y.C., Perlman, R.L., Costopoulos, D., Slayton, V.W., Bloom, S.R.: Production of "ectopic" vasoactive intestinal peptidelike and neurotensin-like immunoreactivity in human pheochromocytoma cell cultures. J. Neurosci. 4: 1404, 1984 
71. Tatsuta, M., Baba, M., Itoh, T.: Increased gastrin secretion in patients with pheochromocytoma. Gastroenterology 84:920, 1983

72. Stewart, H.F., Hoecker, J.L., Mallette, L.E., Segre, G.V., Amatruda, T.T., Vignery, A.: Hypercalcemia in pheochromocytoma: Evidence for a novel mecha-

\section{Invited Commentary}

Timothy S. Harrison, M.D.

Department of Surgery, Aga Khan University, Karachi, Pakistan

Shortly after the development of precise chemical measurement of increased catecholamine excretion in pheochromocytomas, the first biochemical abnormalities of malignant pheochromocytomas were noted. In some malignant pheochromocytomas, there was a proportionately larger quantity of excreted dopamine and its metabolites, such as homovanillic-acid, than is seen in either normal subjects or patients with benign pheochromocytomas. Dopamine is the precursor of norepinephrine. In at least one instance, Dopamine's precursor, dihydroxy-phenyl-alanime (DOPA), was found in the urine of a malignant pheochromocytoma patient. Ordinarily, DOPA is not seen in the urine in either normal subjects or patients with a benign pheochromocytoma. It is the opinion of many that this undifferentiated catecholamine excretion pattern reflects the undifferentiated pattern of malignant pheochromocytoma cells.

It was first suggested through studies of rare patients with adrenal medullary tumors and Cushing's syndrome, in whom catecholamine-secreting tumors contain and release excessive adrenocorticotropic hormone (ACTH), that there are hormones nism. Ann. Intern. Med. 102:776, 1985

73. Kessler, J.A., Adler, J.E., Black, I.B.: Substance P and somatostatin regulate sympathetic noradrenergic function. Science 221:1059, 1983

74. Bradley, J.E., Young, J.D., Lentz, G.: Polycythemia secondary to pheochromocytoma. J. Urol. 86:1, 1961

other than catecholamines that are synthesized and released by pheochromocytoma tissue. We now recognize that ACTH precursors in the pro-opiomelano-cortin endogenous opioid series are released physiologically both by the normal adrenal and by benign pheochromocytomas. To what extent ACTH and its precursors are released from malignant pheochromocytomas is a question of interest for which data would be welcome and can be expected in the near future.

This study of gut hormone levels in pheochromocytomas by Vinik et al. is a welcome insight into the diverse hormonal capabilities of neuroectodermal tumors. The fact that somatostatin, vasoactive intestinal polypeptide, motilin, and substance $\mathrm{P}$ are all present (at least some of the time) is consistent with the concept of hormonal diversity, which is known to be particularly true for tumors of the pancreatic islets. It should not be surprising that malignant pheochromocytomas can show greater hormonal diversity than benign pheochromocytomas.

Many additional observations need to be made. Cholecystokinin, angiotensin II, renin, and thyrotropin releasing factor are all more widespread in body tissues than was initially thought. A positive effect of this commendable study by Vinik and co-workers is that it should stimulate further observations by other interested laboratories as well as by their own. 